\title{
USE OF NETNOGRAPHY IN CONTEMPORARY MARKETING RESEARCH
}

\author{
Kopaničová, J., Klepochová, D., Francová, Z.
}

Janka Kopaničová / University of Economics in Bratislava, Faculty of Commerce, Department of Marketing, Dolnozemská cesta 1, Bratislava, Slovakia.Email: janka.kopanicova@euba.sk

Dagmar Klepochová / University of Economics in Bratislava, Faculty of Commerce, Department of Marketing, Dolnozemská cesta 1, Bratislava, Slovakia.Email: dagmar.klepochova@euba.sk

Zuzana Francová / University of Economics in Bratislava, Faculty of Commerce, Department of Marketing, Dolnozemská cesta 1, Bratislava, Slovakia.Email: zuzana.francova@euba.sk

\begin{abstract}
Netnography, an online qualitative research method that evolved from ethnography, previously typically used in anthropology, is experiencing its boom in contemporary marketing research worldwide. It helps to answer research questions about a variety of topics, and it is used in many different ways. Therefore, each netnographic study is unique, not only contentwise but also in terms of the approach to the use of the method. In the presented paper, the case study research method was applied to aim at the identification of the best practices in contemporary marketing research when using netnography. Based on the analysis of chosen articles published in peer-reviewed academic journals, the paper defines the features of the research problem suitable for the application of netnography, the typical process, and its variances, as well as basic criteria for use. As a result of observed significant differences in applying the method, the paper captures the variability of netnography use in the Model of NET Dimensions of Netnography. The model shows how each netnographic study has to deal with three dimensions of decisions that need to be taken: 'the Niche' - the place 'where' and the group 'whom' it researches, 'the Engagement' - the extent to which the researcher is engaged in the studied community, and 'the Time' - the timeline - 'when' and timespan 'how long'. The combination of all the possibilities of NET dimensions makes netnography so variable, flexible, and adaptable, and therefore a very suitable method for many research problems.
\end{abstract}

Implications for Central European Audience: The paper presents the variety of use of netnography in contemporary marketing research. Although the method originated at the end of the 20th century and is starting to be very popular worldwide, especially with the growth of life online, there is still very little research done using this method in the CEE. Researching the various scholar engines at the time of the article submission, we found very few published studies originating from the CEE. And yet, as the presented paper shows, the method is very well-fitting for a large variety of research problems, and it is very handy, especially now when other qualitative methods are often more difficult to be carried out due to COVID-19 restrictions. The method has the potential to help to answer many of the real businesses' questions as well as to solve some academic puzzles. Therefore, we see a need to promote it within the academic and business community. 
Keywords: netnography; marketing research; consumer research; qualitative research JEL Classification: M31

\section{Introduction}

According to results from many research studies (e.g. Puttaiah et al., 2020; PWC, 2020; Kohli et al., 2020) the years 2020 and 2021 have been extraordinary in many aspects, especially when it comes to consumer behaviour. According to a study of McKinsey agency (Kohli et al., 2020), the change had been unexpectedly tremendous. A sudden shift in needs, purchase planning, in-store behaviour, even in the choice of the way of consumption and post-purchase satisfaction - all have changed dramatically. For some businesses - everything has changed; for others, there are so many new aspects that they do not recognize their customers anymore. Things that had been known for years suddenly work differently. And many businesses must start from the beginning - finding themselves a new market niche, identifying customers, planning something that will work even in the new era (Kohli et al., 2020). Others must redefine the approach to current customers because, according to large consumer research of the world's leading consultancy company PWC (2020), people seem to have changed their priorities with what seems a long-lasting effect on their product/brand preference and overall consumer lifestyle.

It would be amiss to simply estimate the impact of such changes on particular fields of businesses without researching specific details. But how to find out how things changed when according to researchers (Puttaiah et al., 2020), many customers moved not only their purchases but also their community life online? New methods (both quantitative and qualitative) arise and grow in popularity to help to describe the change. One of such is netnography. The method evolved from ethnography, used first mainly by cultural anthropology (Kozinets, 2010). Ethnography was for years used to gain more understanding about distant cultures and closed communities, later about various groups of people, then even to gain knowledge about work teams and most recently also used by marketing research to gain an understanding of consumers by living among them as well as 'in their shoes' (Mariampolski, 2006). With more and more life going on online, ethnography has given birth to a new method called netnography (Kozinets, 2010). Living among a certain online group allows the researcher to understand more of the group dynamics and the product/service features that cause it. Brand lovers, brand haters, indifferent consumers all have their forums. If there is a listening ear and an understanding mind, then netnography can create a great value when planned and used properly.

The aim of the paper is to introduce the method of netnography to a wide range of readers from businessmen to scholars - in an understandable way to show when and how can netnography help and present what could be considered as the best practice when using it.

The first section briefly introduces netnography and, based on literature review, shows how the method evolved what are the main benefits and possible constraints. The section Methods explains how the case study research method was applied to formulate what is the 


\section{DISCUSSION}

best practice when using netnography. The next section presents the findings regarding the use of netnography in contemporary marketing research both for business and scholarly purposes. The article presents a Model of NET Dimensions of Netnography, which explains the most important decisions each researcher has to make before launching the research using netnography. In the end, limitations and findings are discussed and put in the context of current business and marketing research.

\section{Literature review}

Ethnography as a qualitative research method had been used in marketing research already in the past. The main reason was to observe customers and consumers in action. Living daily life among employees of a certain company, or family, or even a community, brings insights that will most probably never occur in interviews or focus groups. It is because very often, people are not aware of certain details that can mean a lot when it comes to innovating a product or service, but a skilled researcher sees the meanings in detail (Mariampolski, 2006; Richterová et al., 2013). That was the case with Lucy Suchman, an anthropologist that conducted ethnographical research for Xerox company. She videotaped the office employees using copy machines featuring the big green button that Xerox had launched in their product with the promise that it would (by use of artificial intelligence) know what needed to be done. But instead of letting the machine do, what was needed, people were trying to understand how the machine works and failed to use it properly. The most famous case of ethnography use in the business environment that became a legend of a giant green button (twisted like many legends are) brought results that helped the Xerox company understand why the copy machine users are failing to use a highly 'intelligent' machine (Chokshi et al., 2011).

At the end of the last century, Robert V. Kozinets applied ethnography into online reality (Kozinets, 1997, 1998) and found a research method that he calls 'Netnography' (Kozinets, 2002). In the beginning, some authors used it as a synonym for digital ethnography, online ethnography, or cyber ethnography, but Mkono and Tribe (2017) see significant differences between ethnography and netnography, and they call it an oversimplification if one was to characterize netnography as 'online ethnography'. As well as Caliandro (2014), Whalen (2018) and Kozinets et al. (2018) argue that netnography is a method on its own because it has its methods and guidelines.

Netnography, as it evolved from ethnography, uses mainly techniques and traditions of cultural anthropology, and that is both in fieldwork as well as in interpreting the findings (Kozinets, 1998). As the main benefits, the following features are often listed:

- The data are rich, naturalistic, and reliable (Alavi, 2014; Kozinets, 2002, 2006; Park, et al., 2019).

- The data collection is unobtrusive, therefore suitable for sensitive topics (Kozinets, 2002, 2006; Langer \& Beckman, 2005).

- The use of the method is faster, simpler, and less expensive than ethnography (Alavi, 2014; Kozinets, 2002; Park et al., 2019).

- It is combinable with traditional qualitative methods such as an in-depth interview or Focus Group (Kozinets, 2006).

- $\quad$ The method is flexible and adaptable (Kozinets, 2010; Heinonen \& Medberg, 2018). 


\section{DISCUSSION}

When it comes to the limits of the method, Heinonen and Medberg (2018), authors of a systematic review and analysis that they conducted on 321 netnography studies published in marketing journals between 1997 and 2017, identified the following issues:

- $\quad$ authenticity and quality of the material - the same limitation states Kozinets in his later papers (e.g. Kozinets et al., 2018), where he emphasizes that since there are more and more chatbots, content generating machines, and automated answers, there is a need to distinguish between genuine human content and the automated one,

- a difficulty to establish the demographics of the researched group, therefore they see the netnographic approach as not very suitable for research sensitive to factors such as age, ethnicity, or even gender,

- and of course, as with all qualitative techniques, there is a large limitation when it comes to generalizing its findings to customer groups outside the online platforms or online communities that were studied.

Scholars often refer to netnography as an approach, methodology, method, set of techniques. The most cited author in this field and the creator of netnography Robert V. Kozinets sees it as a method $(1998,2002,2006,2010,2018)$. And as it is more than twenty years in use, it already has a submethod called auto-netnography (Kozinets \& Kedzior, 2009; Villegas, 2018). Both netnography and auto-netnography aim to understand the online communities, but auto-netnography, unlike netnography, allows the researcher to dive deep into the community not as a spectator but as a participator. The researcher becomes a part of the community, and he/she describes his/her own experience (Mkono et al., 2015) and uses not only observation but introspection as well. Therefore, auto-netnography has a stronger and deeper understanding of the emotional background of the so-called 'stories' (Kozinets et al., 2018; Villegas, 2018).

Netnographic research has been used in different areas. In the beginning, it was mostly sociology (Kozinets, 1997, 1998) psychology (Kozinets, 2002; Nelson \& Otnes, 2005), both somehow often applied to business. Later political science (Tsandzana, 2019), computer science (Del Vecchio et al., 2020), even medicine (Jokipalo \& Khudayarov, 2021), or nutrition and health management (Schier \& Linsenmeyer, 2019). In the field of business, there had been multiple fields that had used netnography as a tool to gain more knowledge about the market, consumers, or customers: tourism industry (Tavakoli \& Mura, 2018; Thanh \& Kirova, 2018), the fashion industry (Xharavina, Kapoulas, \& Miaoulis, 2020), telecommunication industry (Bhattacharyya \& Dash, 2020), celebrity marketing (Logan, 2015), political marketing (Mahestu \& Sumbogo, 2020) even helping to solve issues in brand management (Schembri \& Latimer, 2016), customer relationship management (Bhattacharyya \& Dash, 2020), public relations (Toledano, 2017), consumer behaviour (Wei et al., 2011; Hua et al., 2020) and so many other areas and fields.

Several authors (Kozinets et al., 2018; Bhattacharyya \& Dash, 2020) agree that netnography can offer many valuable insights even in this era of quantitative research and even in quantitative data dominant areas like computer science, telecommunications, or medicine. 


\section{DISCUSSION}

\section{Methods}

Netnography's popularity is rising, as it is apparent from what is written above, especially among progressive researchers. Yet, when researching academic or business journals originating from the CEE region, only a few published papers used netnography. Neither the academics nor the practitioners in CEE use the method intensively. Therefore, we set the goal of the article to introduce the method of netnography to a wide range of readers - from businessmen to academics - in an understandable way to show when and how can netnography help and present what could be considered as the best practice when using it.

To research the use of the method, we decided to conduct case study research that would not only answer our questions about the applicability of netnography but would also show if netnography is what could be called 'a new hope for qualitative research in the COVID-19 world'.

The first step in the research was to identify cases (published as papers), that used netnography as a primary research method. Papers that were subject of the case study research had to fulfil the following criteria:

- use of netnography research method (the word netnography had to be used in the abstract or in the title of the paper),

- published in an academic peer-reviewed journal that was indexed by WoS, Scopus, or ProQuest,

- available to read the full-text (the full article was essential to conduct the case study research about the used methodology),

- written in English,

- netnography was used as a primary research method to solve a business/marketing-related issue.

To identify suitable cases, the ProQuest database, Semantic scholar database, and Google scholar databases were chosen for the first searches - as these databases offer their own full-text access to most of the papers for registered users. More than 1000 articles that fulfilled the first four criteria were then filtered to see if the papers were business/marketing related. First, the subject filters offered by the database engine were used. Depending on the database, the subject filters were chosen to cover the field of business and marketing (e.g. Business, Marketing Research, Customers, Consumers, Consumption, Online Consumption, Brand, Customer Satisfaction, Tourism, Consumer Behavior, Services). Then the refining process took place, and twenty papers were chosen based on their content. Chosen papers not only fulfilled all five criteria but also had to represent different approaches to netnography. They originated from different regions and solved different business/marketing issues. When selecting the papers, the goal in the process was to include papers that presented different use of netnography to capture the diversity of the method's usage.

The case study research method that was chosen to analyze the cases of netnography use enables a researcher to reach a more general knowledge by examining and analyzing real situations, real companies - 'the real cases' employing induction (Richterová et al., 2013). There are two ways how to apply this method to marketing research. The first approach is 


\section{DISCUSSION}

based on the examination of the success of other companies, products, ideas - so-called cases. The method comes up with general conclusions, which could work in case of the currently solved marketing problem, or it can help to formulate generalized recommendations and advice for future cases. The second approach analyzes failures that can reveal the causes or mechanisms of problems. Both approaches generate practical knowledge that can be used for managerial decision-making in the company, as well as theoretical knowledge that comes from understanding the researched issues.

The case studies are often used in the pedagogical process to illustrate the functioning of the phenomena described by the theory to provide students with insight into the reality of the corporate world. However, the case study research aims not to illustrate the theory in practice but to reveal and describe the mechanism that caused the evolution of the case. Based on revealing the principles behind the events, the case study research formulates a 'theory' induced by practical examples (Shuttleworth, 2008; Yin, 2017).

The Case study research method provides the possibility to (Richterová et al., 2013):

- reveal how the studied phenomenon works (HOW does it work?)

- verify or confirm the functioning of the assumption (DOES this theory work at all?)

- $\quad$ explain the causes or consequences (WHY does it work? WHAT will it cause?)

- compare (HOW does it differ under other conditions?)

Myers (2009) sets a set of criteria for a case study research to be considered beneficial. The results should be:

- interesting,

- $\quad$ substantiated by sufficient evidence,

- complete (containing all relevant information), and

- considering alternative perspectives and bringing new knowledge.

Based on the earlier cited main benefits of the case study research method (Richterová et al., 2013), and striving for fulfilling the goal of the article, the paper is searching for answers to the following research questions:

RQ1: What are the basic traits of the market situation (research field) when the method netnography can be used and helpful? (What were the common features? What were the variances? What range of different research topics does the method cover?)

RQ2: How could this method be used effectively to understand consumer needs and wants? (What is the best practice? What is the widely used process? Are there some differences in the process between authors?)

RQ3: What basic criteria need to be met to use netnography properly and with relevance? (Are there some generalizable 'must!' and 'must not!!' when doing the research? Is there a common understanding of research rules?)

The paper searches to find the answers that would be generalizable and would help with formulating basic principles that would serve as advice to companies willing to use 


\section{DISCUSSION}

netnography to better understand their customers and consumers, as well as for academics who want to start with netnography in their research.

\section{Results}

The papers that were chosen for the case study research were purposefully diverse, as it is displayed in Table 1. The focus of the studies, as well as research areas, varied very much. Authors from different continents and countries (Australia; Asia - China; Eurasia - Cyprus, Turkey; Europe - Denmark, Sweden, Spain, Ireland, Germany; America - USA, Canada) researching different products, services or industries (fast-moving goods, electronics, health and beauty services, tourism services, banking) use netnography in different ways to find answers to a variety of business problems or issues (understanding customers' search of information, understanding decision-making process, uncovering perception and motivation, researching niche market, analyzing an impact of word of mouth or even monitoring brand alignment between brand image and brand identity). As a result, the use of netnography brings insights into understanding motives behind customer boycotts, advice to product strategy, distribution channels innovation, targeting, segmenting, typology, branding, and value formation, as well as hints for crisis management. It describes customer information search or decision-making process, all of that in specific market situations of different product categories.

Table 1 shows an overview of research problems and results that were obtained by the use of netnography.

Table 1 | Focus of the netnography studies

\begin{tabular}{|c|c|c|c|c|}
\hline $\begin{array}{l}\text { Author (Year } \\
\text { of publication) }\end{array}$ & Country & $\begin{array}{l}\text { Research area } \\
\text { /industry }\end{array}$ & Research problem/issue & $\begin{array}{r}\text { Results/Business } \\
\text { application }\end{array}$ \\
\hline $\begin{array}{l}\text { R. Kozinets } \\
(2002)\end{array}$ & USA & Coffee / FMG & $\begin{array}{l}\text { Understanding the meaning of } \\
\text { contemporary coffee } \\
\text { consumption. }\end{array}$ & Product strategy advice \\
\hline $\begin{array}{l}\text { R. Langer \& } \\
\text { S.C. Beckman } \\
(2005)\end{array}$ & Denmark & $\begin{array}{l}\text { Plastic surgeries } \\
\text { / Health and } \\
\text { Beauty Industry }\end{array}$ & $\begin{array}{l}\text { Understanding the motivation, } \\
\text { experiences, feelings, attitudes, } \\
\text { and opinions about cosmetic } \\
\text { surgeries. }\end{array}$ & $\begin{array}{r}\text { Understanding the decision- } \\
\text { making process with plastic } \\
\text { surgery. }\end{array}$ \\
\hline $\begin{array}{l}\text { Z. Beaven \& } \\
\text { C. Laws (2007) }\end{array}$ & USA & $\begin{array}{c}\text { Tickets } \\
\text { distribution } \\
\text { channel / Culture }\end{array}$ & $\begin{array}{l}\text { Understanding of perception of } \\
\text { innovative virtual channel } \\
\text { strategy. }\end{array}$ & $\begin{array}{l}\text { Advice on innovating } \\
\text { distribution channels }\end{array}$ \\
\hline $\begin{array}{l}\text { J. Xun \& } \\
\text { J. Reynolds } \\
(2010)\end{array}$ & USA & $\begin{array}{l}\text { Digital cameras / } \\
\text { Electronics }\end{array}$ & $\begin{array}{l}\text { Analyzing an impact of word of } \\
\text { mouth (Logos Pathos Ethos) }\end{array}$ & $\begin{array}{r}\text { Advice on targeting, } \\
\text { segmenting, and analyzing } \\
\text { of online purchase - use of } \\
\text { eWOM }\end{array}$ \\
\hline $\begin{array}{l}\text { K. Braunsberger } \\
\text { \& B. Buckler } \\
(2011)\end{array}$ & USA & Seafood / FMG & $\begin{array}{l}\text { Researching motivation to } \\
\text { consumer boycotts. }\end{array}$ & $\begin{array}{r}\text { Understanding the motives } \\
\text { that cause participating in } \\
\text { boycotts. }\end{array}$ \\
\hline $\begin{array}{l}\text { V. Madupu, K. } \\
\text { Shannahan \& } \\
\text { R. Shannahan } \\
(2013)\end{array}$ & Canada & $\begin{array}{l}\text { Cross border } \\
\text { shopping / } \\
\text { Tourism }\end{array}$ & $\begin{array}{l}\text { Identifying the motivating factors } \\
\text { and barriers of Canadians to } \\
\text { cross-border shopping }\end{array}$ & $\begin{array}{r}\text { Motivators and barriers to } \\
\text { cross border shopping and } \\
\text { understanding the role of } \\
\text { the internet }\end{array}$ \\
\hline $\begin{array}{l}\text { H.G. Larsen } \\
(2014)\end{array}$ & China & $\begin{array}{c}\text { City Shanghai / } \\
\text { Tourism }\end{array}$ & $\begin{array}{l}\text { The perception of the city by } \\
\text { foreigners. }\end{array}$ & City branding \\
\hline
\end{tabular}




\begin{tabular}{|c|c|c|c|c|}
\hline $\begin{array}{l}\text { Author (Year of } \\
\text { publication) }\end{array}$ & Country & $\begin{array}{l}\text { Research area } \\
\text { /industry }\end{array}$ & Research problem/issue & $\begin{array}{r}\text { Results/Business } \\
\text { application }\end{array}$ \\
\hline $\begin{array}{l}\text { G. Medberg \& } \\
\text { K. Heinonen } \\
(2014)\end{array}$ & Sweden & Banking & $\begin{array}{l}\text { What value factors are present in } \\
\text { a bank-customer relationships? }\end{array}$ & $\begin{array}{r}\text { Advice on value formation in } \\
\text { the customer-bank } \\
\text { relationship }\end{array}$ \\
\hline $\begin{array}{l}\text { S. Sloan, } \\
\text { K. Bodey \& } \\
\text { R.G. Jones } \\
(2015)\end{array}$ & Australia & $\begin{array}{l}\text { Cruise liner } \\
\text { company / } \\
\text { Tourism }\end{array}$ & $\begin{array}{l}\text { How does knowledge sharing } \\
\text { take place in firm-sponsored } \\
\text { versus user-generated online } \\
\text { brand communities? }\end{array}$ & $\begin{array}{r}\text { Understanding the } \\
\text { differences in user- } \\
\text { generated and firm- } \\
\text { sponsored online brand } \\
\text { communities. }\end{array}$ \\
\hline $\begin{array}{l}\text { M. Toledano } \\
(2017)\end{array}$ & USA & $\begin{array}{l}\text { meetup.com / } \\
\text { Public Relations }\end{array}$ & $\begin{array}{l}\text { Insights into understanding the } \\
\text { sponsor-organizer relationship. }\end{array}$ & PR management advice \\
\hline $\begin{array}{l}\text { J.S. Clemente- } \\
\text { Ricolfe (2017) }\end{array}$ & Spain & $\begin{array}{l}\text { Online banking / } \\
\text { Banking }\end{array}$ & $\begin{array}{l}\text { Understanding of positioning of } \\
\text { online banking. }\end{array}$ & Positioning advice \\
\hline $\begin{array}{l}\text { T. Özbölük \& } \\
\text { Y. Dursun } \\
\text { (2017) }\end{array}$ & Turkey & $\begin{array}{l}\text { Apple products / } \\
\text { Electronics }\end{array}$ & $\begin{array}{l}\text { Researching the types of online } \\
\text { brand community members }\end{array}$ & Typology of forum users \\
\hline $\begin{array}{l}\text { G.S. Nunes \& } \\
\text { E.J.M. Arruda } \\
\text { Filho (2018) }\end{array}$ & $\begin{array}{l}\text { World wide } \\
\text { web } \\
\text { (English) }\end{array}$ & $\begin{array}{l}\text { Google Glass / } \\
\text { Electronics }\end{array}$ & $\begin{array}{l}\text { Analyzing consumer behavior of } \\
\text { Google glass users }\end{array}$ & $\begin{array}{r}\text { Typology of innovative } \\
\text { consumer. Insights for } \\
\text { launching of new hi-tech } \\
\text { products. }\end{array}$ \\
\hline $\begin{array}{l}\text { P. Paraskevaidis } \\
\text { \& } \\
\text { A. Weidenfeld } \\
(2019)\end{array}$ & Ireland & $\begin{array}{c}\text { Titanic Belfast } \\
\text { Tourist Attraction } \\
\text { /Tourism }\end{array}$ & $\begin{array}{l}\text { Investigate consumer behavior } \\
\text { and sign perception in visitor } \\
\text { attractions }\end{array}$ & $\begin{array}{r}\text { A deeper understanding of } \\
\text { sign consumption and sign } \\
\text { promotion }\end{array}$ \\
\hline $\begin{array}{l}\text { E. Park, G. Im, } \\
\text { V.C. Storey \& } \\
\text { R.L. Baskerville } \\
(2019)\end{array}$ & $\begin{array}{l}\text { worldwide } \\
\text { web } \\
\text { (English) }\end{array}$ & $\begin{array}{l}\text { IT products / } \\
\text { Electronics }\end{array}$ & $\begin{array}{l}\text { Understanding of the value } \\
\text { creation by online support } \\
\text { communities. }\end{array}$ & $\begin{array}{r}\text { Insights into the value } \\
\text { creation by online support } \\
\text { communities in post- } \\
\text { purchase management of } \\
\text { negative customer emotion }\end{array}$ \\
\hline $\begin{array}{l}\text { L. Hua, C. } \\
\text { Prentice \& X. } \\
\text { Han }(2020)\end{array}$ & China & $\begin{array}{l}\text { mafengwo.cn / } \\
\text { Tourism }\end{array}$ & $\begin{array}{l}\text { Typologizing customers' reactions } \\
\text { in case of company misconduct. }\end{array}$ & Crisis management advice \\
\hline $\begin{array}{l}\text { S. Villers, } \\
\text { R. Abrams, } \\
\text { S. Anderson, } \\
\text { M. Aung \& } \\
\text { E. Sweeney } \\
(2020)\end{array}$ & $\begin{array}{l}\text { worldwide } \\
\text { web } \\
\text { (English) }\end{array}$ & $\begin{array}{l}\text { Wearable } \\
\text { technology Fitbit } \\
\text { / Electronics }\end{array}$ & $\begin{array}{l}\text { What theoretical and managerial } \\
\text { insights can be gained from the } \\
\text { brand community? }\end{array}$ & $\begin{array}{r}\text { Understanding of a niche } \\
\text { customer segment }\end{array}$ \\
\hline $\begin{array}{l}\text { N. Uzunboylu, } \\
\text { Y. Melanthiou \& } \\
\text { I. Papasolomou } \\
(2020)\end{array}$ & Cyprus & $\begin{array}{l}\text { Brands / } \\
\text { Consumer } \\
\text { goods }\end{array}$ & $\begin{array}{l}\text { Researching the selfie } \\
\text { phenomenon and its interactivity } \\
\text { between brands and target } \\
\text { audiences. (Instagram) }\end{array}$ & $\begin{array}{r}\text { Advice on consumers' both } \\
\text { consumption and } \\
\text { production of brand } \\
\text { meanings in digital } \\
\text { platforms }\end{array}$ \\
\hline $\begin{array}{l}\text { M. Dressler \& } \\
\text { I. Paunovic } \\
(2021)\end{array}$ & Germany & Wine / FMG & $\begin{array}{l}\text { Discovering brand strategy of } \\
\text { SME wineries in Germany }\end{array}$ & Brand strategy \\
\hline $\begin{array}{l}\text { S. Ranfagni, M. } \\
\text { Faraoni, L. Zollo } \\
\& \\
\text { V. Vannucci } \\
(2021)\end{array}$ & $\begin{array}{c}\text { worldwide } \\
\text { web } \\
\text { (English) }\end{array}$ & $\begin{array}{l}\text { Nespresso / } \\
\text { Electronics }\end{array}$ & $\begin{array}{c}\text { Monitoring brand alignment } \\
\text { between brand image and brand } \\
\text { identity }\end{array}$ & $\begin{array}{r}\text { Methodology how to } \\
\text { measure brand alignment } \\
\text { between brand image and } \\
\text { brand identity }\end{array}$ \\
\hline
\end{tabular}

Source: authors' own elaboration 


\section{DISCUSSION}

Results of looking deeper into the methodology of chosen papers using netnography as their primary research method led to answering our RQ1 about basic traits of the market situation when netnography can be considered as a suitable research method (subsection 3.1); RQ2 best practice or a typical process and its variances when conducting netnography research (subsection 3.2); RQ3 criteria that are necessary to fulfil during field research and in the process of data processing and interpretation of results (subsection 3.3). In the end, the understanding of different approaches to using the method led to the creation of a system of NET dimensions of netnography that define every netnographic research (subsection 3.4).

\subsection{When can netnography be seen as a suitable research method?}

As we mentioned earlier, netnography has been used in various fields, industries, and science fields to help by uncovering the true nature of the problem. What are the basic characteristics that connect the researched case studies? What is the common characteristic of the issue, determining it to be suitable for the use of netnography? In the majority (and with some elements even in all) researched papers, we found the following common grounds.

- At first, the problem that the market experiences or that the researchers need to solve is more precisely definable as 'AN ISSUE'. It is because often the researchers do not know what causes it or what are the consequences, what are the roots, sometimes they do not even have 'the problem' just the field that needs to be researched to bring understanding to be able to formulate some basic theories, hypotheses about how things are. Literature calls this an unstructured problem. The most important is that the issue must be decomposable into research questions.

- The researched issue always INVOLVES PEOPLE and their perception, understanding, experiences, ideas, opinions, etc. In the research, the understanding of what had been posted online and the capability to find a common and essential feature in it, as well as the ability to give it a meaningful structure - that is the key to good netnographic study.

- The research field is always ACCESSIBLE ONLINE. The people whose understanding, ideas, and experiences are the research ground must post online in some form. Usually, it is an online community that is somehow connected to the research issue. Recently there have been netnographic research projects that used vlogs (e.g. Schier \& Linsenmeyer, 2019) or photos (Uzunboylu et al., 2020), but most of the published studies use written posts, comments, forum contributions, blogs, etc. Some communities are exclusive; therefore, access for researchers must be granted by the company that has the right to allow the access, but most of the research is done on open online platforms.

Usage of netnography in researched papers had various goals. Some authors used it primarily to formulate theoretical models or postulates (e.g. Hua et al., 2020; Kozinets, 2002; Paraskevaidis \& Weidenfeld, 2019; Ranfagni et al., 2021; Uzunboylu et al., 2020). Others had in mind mostly practical advice for a specific market situation of the chosen product category (e.g. Clemente-Ricolfe, 2017; Nunes \& Arruda Filho, 2018; Özbölük \& Dursun, 2017). But as 


\section{DISCUSSION}

all of the case studies were papers published in peer-reviewed academic journals, all research papers brought a certain amount of both - theoretical insights as well as practical implications, as netnography can bring both.

To answer the RQ1 (What are the basic traits of the market situation (research field) when the method can be used and helpful?), the following has to be said as a result of understanding the variety of researched topics. Netnography is usable if the research problem is more a research question, research topic to which answers can be found in understanding what consumers/users/customers or employees think AND post online. As well in the case of looking for a niche that could become a business plan, the product and topic forums can be very helpful (as it was for example with the case of Fitbit wearable HiTech product, where the researchers found out that a certain quite significant group of consumers use Fitbit watch to mainly monitor the quality of their sleep, instead of using it to measure their training or fitness condition (Villers et al., 2020).

\subsection{How is netnographic research carried out?}

How could this method be used effectively to understand consumer needs and wants? What should be the steps when using netnography? (RQ2)

Most of the currently published case studies use the Kozinets' netnographic research study flow (Scheme 1). There are some small variances, but as the Kozinets' scheme is an adaptation of the typical qualitative research process, there is not too much to change.

\section{Scheme 1 | Kozinets's simplified flow of netnographic research project}

\begin{tabular}{|c|c|}
\hline 1 & $\bullet$ Definition of research questions, or research issues \\
\hline 2 & $\cdot$ Community identification and selection \\
\hline 3 & $\cdot$ Data collection \\
\hline 4 & $\cdot$ Data analysis and iterative interpretation \\
\hline 5 & $\cdot$ Presentation of research findings and implications \\
\hline
\end{tabular}

Source: Kozinets (2010)

At first, the researchers determine the research area - what needs to be looked for and where. With netnography (as with most of the qualitative research methods), there are no hypotheses to be confirmed, only research questions to be answered. In this type of research, it is enough to define what is the research field - either topic that needs to be investigated or issues that will be the ground. Often the area is defined based on either product, commodity, brand, service (e.g. google glass, Nunes \& Arruda Filho, 2018; online banking, Clemente-Ricolfe 2017; tourist site, Larsen, 2014; Paraskevaidis \& Weidenfeld, 2019) or problem (e.g. customers' reactions to company's misconduct, Hua et al., 2020, information diffusion between customers and company, Sloan et al., 2015) or online community (e.g. boycotts petition signatories, Braunsberger \& Buckler, 2011; coffee enthusiasts, Kozinets, 2002). 


\section{DISCUSSION}

In the next step, the online community that could give answers to research questions must be identified and selected. It is very important to choose a relevant group. There are often multiple communities dealing with the same issues, and therefore a selection process including a short-term observation often proceeds the decision of which one (or several) should be chosen. Before the final choice is made, Kozinets (2015) recommends applying a five-fold examination criterion. The online community needs to be (1) a focused research relevant group with (2) high traffic of postings and (3) a large number of discrete posters or members that post (4) rich descriptive data and (5) have high interaction between members. Most of the researched papers followed at least 4 of 5 examination criteria when choosing the online platform or group. Some studies - given their specific goal - could not fulfil all of them (e.g. Braunsberger \& Buckler (2011) had no member interaction, as the study was based on notes that signatories of the petition sent to the Canadian government).

After the choice of community, the researcher enters the online group to collect data. He/she can choose either to only observe (read) actions and interactions of the members, or he/she decides to collect data also by interacting with the group. The cases we researched used both levels of interaction. The choice of the approach was dependent on the research topic and research goal, the number of posts already covering the researched area, and the level of group interactions. In this step, netnography ethics is a very discussed issue. Should the researcher uncover his/her intentions, or should he/she remain quiet? How to deal with the privacy issues of the group members? Can a researcher fake identity to find out more? As the method of netnography comes from principles of cultural anthropology, it 'shares its values' and, therefore, it is advised (Kozinets, 2010) to not invade the community, nor to disrupt existing culture and disbalance the present relationships in the group. The researcher is advised to either observe and not intervene or to blend into the community. In the case, that researcher becomes personally engaged or even immersed into the group and its topic, the netnography becomes an auto-netnography (e.g. Kozinets \& Kedzior, 2009). In this phase, some studies (e.g. Toledano, 2017) chose to even contact active online posters to gain more understanding (via e-mail, private chats, etc.).

Unlike with many other methods that collect the data and then analyze them, in netnography data collection, analysis and interpretation are often done in a spiral. Collect, analyze, interpret, collect, analyze, interpret until the whole issue is more clear and somehow structured. Findings build on previous findings, constructing a concept that is tested and verified again by collecting more data. As with all qualitative methods, data and findings triangulation is necessary. Most of the studies claimed the use Grounded Theory Method as an approach to analyzing data. Some studies used computer-aided analysis - software that was used was either NVivo (Özbölük \& Dursun, 2017; Villers et al., 2020) or combined with MS Excel (Hua et al., 2020) or authors did not mention the brand. Usually, the analysis started with frequency analysis, followed by topical coding and content analysis. They were subsequently formulating postulates often testing them with other sets of data. Summarizing the findings, some authors (e.g. Özbölük \& Dursun, 2017) even returned to the research field and presented their findings to chosen active online participants, asking for their view on concepts that they discovered. 


\section{DISCUSSION}

Table 2 | Data source and time span

\begin{tabular}{lcr}
\hline $\begin{array}{l}\text { Author } \\
\text { (Year of publication) }\end{array}$ & $\begin{array}{c}\text { Time span of } \\
\text { researched } \\
\text { data }\end{array}$ & $\begin{array}{c}\text { Entry data/ } \\
\text { Participants }\end{array}$ \\
\hline
\end{tabular}

R. Kozinets (2002)

R. Langer \&

S.C. Beckman (2005)

Z. Beaven \&

C. Laws (2007)

J. Xun \&

J. Reynolds (2010)

K. Braunsberger \& B. Buckler (2011)

V. Madupu, K. Shannahan \&

R. Shannahan (2013)

H.G. Larsen (2014)

G. Medberg \&

K. Heinonen (2014)

S. Sloan, K. Bodey \& R.G. Jones (2015)

M. Toledano (2017)

J.S. Clemente-Ricolfe (2017)

T. Özbölük \& Y. Dursun (2017)

G.S. Nunes \&

E.J.M. Arruda Filho (2018)

P. Paraskevaidis \&

A. Weidenfeld (2019)

E. Park, G. Im, V.C. Storey \&

R.L. Baskerville (2019)

L. Hua, C. Prentice \& X. Han (2020)

10 days

S. Villers, R. Abrams, S. Anderson, M.

Aung \&

5 years

E. Sweeney (2020)

N. Uzunboylu, Y. Melanthiou \&

I. Papasolomou (2020)

2 months

M. Dressler \&

I. Paunovic (2021)

S. Ranfagni, M. Faraoni, L. Zollo \&

V. Vannucci (2021)

17 months

2 weeks

4 months

2 months

1 year

4 years

12 years

2 weeks

2,5 years

18 months

4 months

6 months
33 months

out of 1676 TripAdvisor postings, authors chose 133 representative and meaningful

out of 12905 posts on two online customer service communities, authors chose 100 that were fulfilled the

criteria

4565 posts that were written as a reaction to the company's misconduct

6835 posts on the Fitbit forum

74 brand selfies

895 wineries (webs and online information)

netnography and text mining, data from both companygenerated content as well as user-generated messages.

Source: authors' own elaboration 


\section{DISCUSSION}

In step three (data collection) and step four (data analysis and iterative interpretation), authors of researched cases used different approaches. As Table 2 shows, the time span that they decided to analyze to understand the topic varied from 10 days in case of analyzing reactions to the company's misconduct (Hua et al., 2020) to 12 years when analyzing bank-customer relationships (Medberg \& Heinonen, 2014). The time span means how wide back to the past the research went, not how long it lasted or how long did the researchers collect the data the duration of the research, of course, was different. The data collection usually lasted days to months (e.g. Medberg \& Heinonen, 2014 analyzed data produced in 18 online communities over 12 years, but they collected them in only 4 days). The data analysis duration was in the papers rarely made known.

As it is clear from Table 2, the volume, range, and scope of data sources vary from research to research. Some case studies analyzed hundreds to thousands of posts and used a quantitative approach to the researched topic at first (e.g. Hua et al., 2020; Villers et al., 2020). Others chose to select less numerous extents but a qualitative approach from the beginning (e.g. Toledano, 2017; Uzunboylu et al., 2020). And of course, it was not only the matter of how many posts were analyzed but also how diverse the sources were (the number of posters and sites or communities). This all combined created a very wide range of ways in which netnography can be used. The use of the method is therefore very flexible, and its use is variable and different from case to case.

The last step of the netnography process is to present the research findings and their implications. With the cases we studied, findings were used both for commercial use and academic presentation (as all were presented in academic journals). As it was obvious from the cases we focused on, netnography can be of good use for businesses regardless of their volume or domain.

\subsection{Basic criteria for the use of netnography}

To answer RQ3 (What basic criteria need to be met to use netnography properly and with relevance?), we had to look more into the methodology and discussion section of the chosen case studies. All authors emphasize that research must be done ethically. But not all authors understand the 'ethics of netnography' in the same way. Two main streams are currently definable - one, the original Kozinets' idea that ethical means being open about doing the research (Kozinets, 2002, 2007, 2010). That means that researchers work openly in the online community, introduce themselves and eventually present and consult findings with the active members. The second stream uses the data that are openly presented on the internet without consulting/ notifying their authors (online posters, members of communities) but making sure that their identities stay anonymous. This approach was first largely advocated by Langer and Beckman (2005). Whichever approach to this issue of research ethics the cases we studied had, authors always emphasized that anonymity of researched subjects is a top priority, together with avoiding intruding and disrupting the online community social system. Therefore, many researchers (Paraskevaidis \& Weidenfeld, 2019; Uzunboylu et al., 2020; Ranfagni et al., 2021; Dressler \& Paunovic, 2021) chose for analysis only either real-time non-participative observation or archival data. 


\section{DISCUSSION}

The next important criterion is to choose a relevant community. Only the correctly chosen community can offer true and valuable insights; therefore, the group selection needs to be done very carefully. In the chosen studies, the community relevancy was either discussed in the beginning (as it was the aim to study this community and find more about it) or often advocated in the last section - discussion (based on the results that were either consulted with some group members, or triangulated with other sources, or extracted from different sources - more communities, more sites, more platforms).

The question of authenticity and falsification of data seems to be a natural result of anonymity or pseudo-anonymity in the online world. But according to Kozinets (2010), who cites several pieces of research done in this area, people often fake identities (either to protect themselves - usually women, or to boost their ego - usually men), but the nature of their understanding, feeling, ideas and perspectives, does not derive from the truth significantly (Kozinets, 2010). Therefore, it is not the data but the analysis and interpretation that can become misleading in the case of superficial research. Therefore, the spiral approach and the triangulation are used to bring reliable results.

Generalization of the findings is, of course, the issue we cannot omit when speaking about criteria for netnography use. As with most results that come from qualitative research, there is a limited possibility to generalize them. But, when the research findings answer specific questions, it often helps to set another round of similar research in a different community and verify the extent of applicability of results in a different environment. All the studied cases defined the range of their applicability and extent of generalization, usually also explaining what steps needed to be taken to expand the extent of generalization of the results.

\subsection{NET dimensions of netnography}

Understanding the use of netnography in contemporary marketing research, which originated from the case study research, led to formulating the Model of NET Dimensions of Netnography. Scheme 2 represents how each netnographical study has to deal with three dimensions of decisions that need to be taken - 'the Niche' - the place 'where' and the group 'whom' the researchers study, 'the Engagement' - the extent to which the researcher will be engaged in the studied community and what will be done there, and 'the Time' - the timeline - 'when' and timespan 'how long'. Of course, combining all these possibilities makes the netnography so variable and flexible, as well as adaptable, and therefore a very suitable method for many research problems.

The decision about the NICHE - means choosing an online space where the studied material is to be gathered, where the data are available, where the real people chat or post about the topic that the researcher lacks an understanding of. The decision needs to be taken about whom will the study observe and where these online posters are located. The 'online niche' - can be found on one website - chat room, page, forum, community, etc., or on several pages that are alike or even on multiple platforms - combining different types of groups focused on the researched topic (e.g. Facebook fan page, online community, and webpage reference section). 
Scheme 2 | Model of NET dimensions of netnography

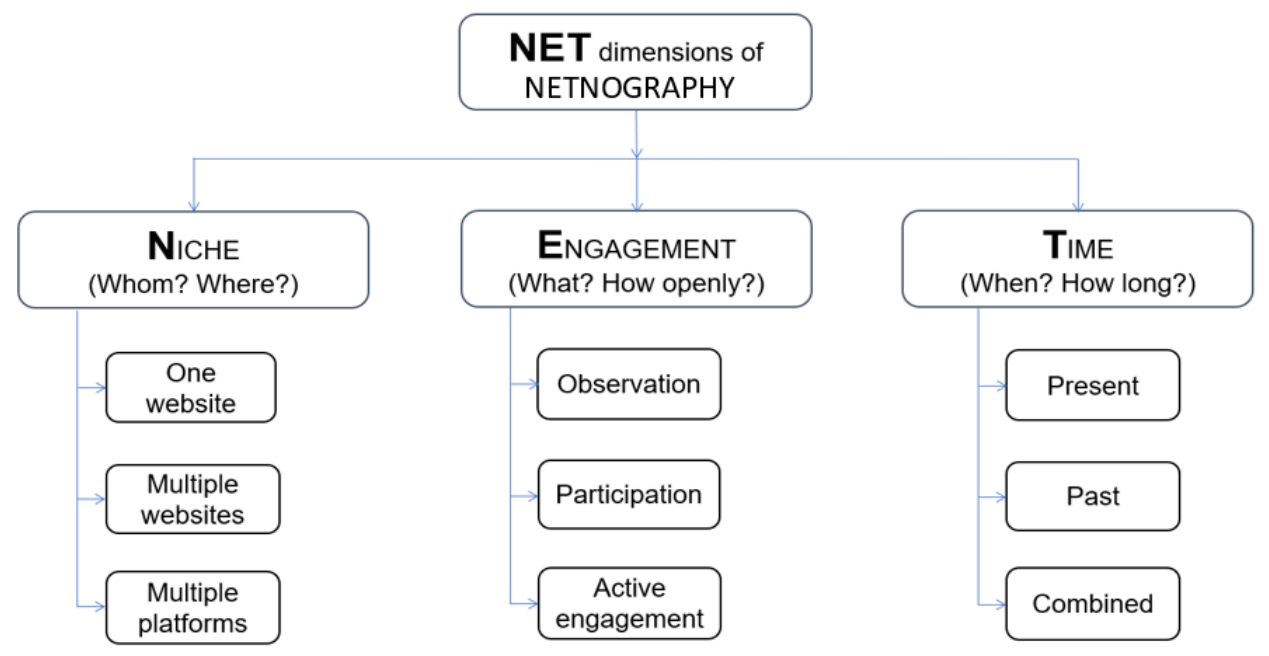

Source: authors' own elaboration

Earlier discussed aspect of immersion into the online community creates the second dimension of decisions that need to be taken. The extent of ENGAGEMENT of the researcher in the online group, community, or problem can vary. The easiest choice is a non-participative observation - that means the group posts online, and the researcher uses the data that are available. The great advantage is that data can be collected without intruding on the community and, therefore, with the least interference. The minus of this approach is that there is often a need to gather a lot of data to find answers to research questions, as the researcher decides to not ask, just to wait that the subject will come up in the conversation somehow. The second option is a participative observation, and that means becoming a part of the group. This can be done either undercover or openly - as it was discussed sooner in the text. Currently, most cited authors on this topic (Kozinets, 2010; Langer \& Beckman, 2005), do not have the same approach. Kozinets (2010) advocates for admitting that the research is being done, Langer and Beckman (2005) advocate for ethics without too much noise, especially when researching sensitive topics. Depending on the extent to which the researcher will be open about his presence in the group, the advantages and disadvantages of the choice change. In the case of openness - the group can 'close' on the topic, or participants can either stop being honest, or it can trigger negative emotions. On the other hand, in the case of cooperation of participants, the research can come up with more relevant results much sooner, compared to the first approach. The third possibility is to become not only a part of the group but to actively participate in the online life of the group, even interviewing the members in private chats, via e-mails, or other ways, organizing the group in a certain way. This usually requires uncovering the nature of interest, and therefore it could bring pluses and minuses mentioned earlier with the disclosed participative observation.

Duration of the research, the time span of the collected data, and the decision if the data should be archival, collected in real-time, or combined - this is the interdependent content of 


\section{DISCUSSION}

the TIME dimension. Advantages of the decision for archival data are clear - availability and readiness - data are online, available to be fully downloaded in hours or days. On the other hand, a disadvantage is that these data are only subject to observation without a possibility to participate in the community to gain a deeper understanding. Real-time data collection is usually interconnected with participative observation or active participation and therefore is much more time demanding when collecting the data but usually brings answers to research questions with fewer ballast data. A combination of the previous two - real-time participant observation or active participation together with analyzing archival data seems to be a winwin, but of course, it is not always feasible. The decision about the timespan is usually made depending on how much data is needed to find answers to the research questions and how high 'the traffic' of the community is. The more active the community is on the topic, the less 'archival' data are needed.

\section{Discussion and conclusions}

The use of netnography has increased exponentially in the past twenty years (Heinonen \& Medberg, 2018), but still, it is very new, and among companies and marketing researchers not a well known method. In 2018 Journal of Marketing Management had a Call for papers on netnography, and according to Kozinets (2018), who was the co-editor of the special issue, they did not even receive enough submissions to make the issue; therefore, they only made a special section on netnography in the journal (Journal of Marketing Management, volume 34 , issue 3-4). When using the academic search engines with the word 'netnography', the results are in several thousands, not in hundreds of thousands like with other research methods (e.g. webofscience.com shows 1023 publications out of which 871 were published articles, semanticscholar.org shows 1210 peer-reviewed articles and books with this topic, academia.edu 84 with title search and 4407 with full-text search, scholar.google.com shows 11600 results including non-English and not peer-reviewed papers). Therefore, since the method has the potential to help to answer many of the real businesses' questions as well as to solve some academic puzzles, there is a need to investigate the use of the method deeper and promote it within the academic and business community.

Researching the way that netnography is being used for business and scholars' research purposes shows that the method is very flexible and adaptable to a very wide range of market situations. When the options of the approach to Niche, Engagement, and Time dimensions (defined in the NET dimensions) combine, the method offers large variability for researching almost anything that falls under the following conditions: -1 . the research problem is rather "AN ISSUE" because it is unstructured; 2 . the issue INVOLVES PEOPLE and their perception, understanding, experiences, ideas, opinions; 3 . the research field is ACCESSIBLE ONLINE.

The case study research that was carried out to answer the research questions and build the base for fulfilling the main goal of the article - to introduce the method netnography to a wide range of readers - from businessmen to academics - in an understandable way to show when and how can netnography help, and present what could be considered as the best practice when using it, had the following main limitations: 


\section{DISCUSSION}

A) an extent of information that authors of articles were willing to share about the methodology /process of carrying out the netnography research. It is probable that many authors consider the detailed methodology personal know-how - as some of the published articles were the result of research done primarily for business purposes, and the academic paper publication was a secondary goal. Therefore, many papers had to be excluded from the study even though they had fulfilled the first set of criteria.

B) limited generalization of results that comes with qualitative research. The research tried to cover as wide range of different uses of the method as possible to show that it is usually very dependent on the researcher him/herself which 'way' they choose. Therefore, even the presented quite a large scale of possible combinations of different approaches that could appear in netnography might not cover a special approach of certain creative researchers. Especially with qualitative research, new ways of applying it might appear. But that is how the method evolves, and with time we might see more studies analyzing photos (like the study of brand interactivity with consumers (Uzunboylu et al., 2020)), or even videos (like in the study of brand-related monetarizing activities of YouTube influencers (Gnegy, 2017)) or something new and innovative. Therefore, the presented results show what some of the currently used ways of netnography usage are, but not all possible.

Nevertheless, the conducted case study research shows netnography as a qualitative method that can be very helpful in answering a variety of research questions. The most attractive about the method is that netnography (as well as auto-netnography) provides not only rich and naturalistic data but can also be conducted about sensitive subjects and, most importantly, even in the times when all the other qualitative methods and techniques that require human interactions, such as, for example, ethnography, focus groups or in-depth interviews are not realizable. In times like that, netnography rises to become the 'new hope for qualitative research in COVID-19 world'. And it will probably be a very useful method also in the times after.

\section{Acknowledgment}

The paper has been written as a part of solving the grant project VEGA 1/0505/22 Implementation of innovative research methods and techniques in the consumer behaviour research in the conditions of the Slovak market of research suppliers and research buyers.

\section{References}

Academia.edu | Search | netnography. Academia.edu. (2021). Retrieved 11 February 2021, from https://www.academia.edu/search?q=netnography.

Alavi, S. (2014). Netnography: An Internet-optimized ethnographic. In A. Takhar-Lail \& A. Ghorbani (Eds.), Market research methodologies: Multimethod and qualitative approaches (71-77). IGI Global.

Beaven, Z., \& Laws, C. (2007). 'Never let me down again'1: Loyal customer attitudes towards ticket distribution channels for live music events: A netnographic exploration of the US leg of the Depeche Mode 2005-2006 World Tour. Managing Leisure, 12(2-3), 120-142. https://doi.org/10.1080/13606710701339322 


\section{DISCUSSION}

Bhattacharyya, J., \& Dash, M. K. (2020). Investigation of customer churn insights and intelligence from social media: A netnographic research. Online Information Review, 45(1), 174-206. https://doi.org/10.1108/OIR-02-2020-0048

Braunsberger, K., \& Buckler, B. (2011). What motivates consumers to participate in boycotts: Lessons from the ongoing Canadian seafood boycott. Journal of Business Research, 64(1), 96-102. doi:10.1016/j.jbusres.2009.12.008

Caliandro, A. (2014). Ethnography in digital spaces: Ethnography of virtual worlds, netnography, \& digital ethnography. In P. Sunderland, P. \& R. Denny (Eds.), Handbook of anthropology in business (738-761). Routledge.

Chokshi, S., Vinkhuyzen, E., Bellotti, V., \& Jordan, B. (2011, January 27). Busting the myth of the giant green button A brief history of corporate ethnography. The true story of ethnography at PARC, and how it reveals the power of ethnography. Uxmag.com. https://uxmag.com/articles/bustingthe-myth-of-the-giant-green-button

Clemente-Ricolfe, J. (2017). Consumer perceptions of online banking in Spain using netnography: A positioning story. The International Journal of Bank Marketing, 35(6), 966-982. https://doi.org/10.1108/JJBM-08-2016-0113

Del Vecchio, P., Mele, G., Passiante, G., Vrontis, D., \& Fanuli, C. (2020). Detecting customers' knowledge from social media big data: Toward an integrated methodological framework based on netnography and business analytics. Journal of Knowledge Management, 24(4), 799-821. https://doi.org/10.1108/JKM-11-2019-0637

Dressler, M., \& Paunovic, I. (2021). A typology of winery SME brand strategies with implications for sustainability communication and co-creation. Sustainability, 13(2), 805. https://doi.org/10.3390/su13020805

Gnegy, H. R. (2017). Beauty and the brand: A digital ethnography of social capital and authenticity of digital beauty influencers through monetization activities on YouTube [Dissertation thesis] (online). https://researchrepository.wvu.edu/cgi/viewcontent.cgi?article=6724\&context=etd

Heinonen, K., \& Medberg, G. (2018). Netnography as a tool for understanding customers: Implications for service research and practice. Journal of Services Marketing, 32(6), 657-679. https://doi.org/10.1108/JSM-08-2017-0294

Hua, L.-L., Prentice, C., \& Han, X. (2020). A netnographical approach to typologizing customer engagement and corporate misconduct. Journal of Retailing and Consumer Services, 59, 102366. https://doi.org/10.1016/j.jretconser.2020.102366

Jokipalo, I., \& Khudayarov, A. (2021). A netnography and a survey on doping use among competitive doping-untested strength-sport athletes. International Journal of Sports Medicine, 42(7), 645650. https://doi.org/10.1055/a-1342-7312

Kohli, S., Timelin, B., Fabius, V., \& Moulvad-Veranen, S. (2020, July 30). How COVID-19 is changing consumer behavior - Now and forever. Mckinsey.com. https://www.mckinsey.com/industries/retail/our-insights/how-covid-19-is-changing-consumerbehavior-now-and-forever

Kozinets, R. (1997). 'I want to believe': A netnography of the X-Philes' subculture of consumption. Advances in Consumer Research, 24, 470-475.

Kozinets, R. (1998). On netnography: Initial reflections on consumer research investigations of cyberculture. Advances in Consumer Research, 25, 366-371. 


\section{DISCUSSION}

Kozinets, R. (2002). The field behind the screen: Using netnography for marketing research in online communities. Journal of Marketing Research, 39, 61-72. https://doi.org/10.1509/jmkr.39.1.61.18935

Kozinets, R. (2006). Click to connect: Netnography and tribal advertising. Journal of Advertising Research, 46(3), 279-288. https://doi.org/10.2501/S0021849906060338

Kozinets, R. (2010). Netnography. Doing ethnographic research online. Sage

Kozinets, R., Scaraboto, D., \& Parmentier, M. (2018). Evolving netnography: How brand autonetnography, a netnographic sensibility, and more-than-human netnography can transform your research. Journal of Marketing Management, 34(3-4), 231-242. https://doi.org/10.1080/0267257X.2018.1446488

Kozinets, R. V., \& Kedzior, R. (2009). I, Avatar: Auto-netnographic research in virtual worlds. In N.T. Wood \& M.R. Solomon (Eds.), Virtual Social Identity and Consumer Behavior (3-19). Routledge.

Langer, R., \& Beckman, S. C. (2005). Sensitive research topics: Netnography revisited. Qualitative Market Research, 8(2), 189-203. https://doi.org/10.1108/13522750510592454

Larsen, H. (2014). The emerging Shanghai city brand: A netnographic study of image perception among foreigners. Journal of Destination Marketing and Management, 3(1), 18-28. https://doi.org/10.1016/j.jdmm.2013.12.003

Logan, A. (2015). Netnography: Observing and interacting with celebrity in the digital world. Celebrity Studies, 6(3), 378-381. https://doi.org/10.1080/19392397.2015.1062652

Madupu, V., Shannahan, K., \& Shannahan, R. (2013). Motivating factors, barriers, and the role of the internet: A netnographic study of Canadian cross-border shoppers. International Journal of Management Research and Reviews, 3(8), 3184-3198.

Mahestu, G., \& Sumbogo, T. A. (2020). Marketing of identity politics in digital world (Netnography study on Indonesian presidential election 2019). 2020 International Conference on Information $\begin{array}{llll}\text { Management and } & \text { Technology }\end{array}$ https://doi.org/10.1109/ICIMTech50083.2020.9211242.

Mariampolski, H. (2006). Ethnography for marketers. Sage.

Medberg, G., \& Heinonen, K. (2014). Invisible value formation: A netnography in retail banking. The International Journal of Bank Marketing, 32(6), 590-607. https://doi.org/10.1108/IJBM-03-20140041

Mkono, M., \& Tribe, J. (2017). Beyond reviewing: Uncovering the multiple roles of tourism social media users. Journal of Travel Research, 56(3), 287-298. https://doi.org/10.1177/0047287516636236

Mkono, M., Ruhanen, L., \& Markwell, K. (2015). From netnography to autonetnography in tourism studies. Annals of Tourism Research, 52, 167-169. https://doi.org/10.1016/j.annals.2015.03.002

Myers, M. D. (2009). Qualitative research in business \& management. Sage.

Nelson, M., \& Otnes, C. C. (2005). Exploring cross-cultural ambivalence: A netnography of intercultural wedding message boards. Journal of Business Research, 58(1), 89-95. https://doi.org/10.1016/S0148-2963(02)00477-0

Nunes, G. S., \& Arruda Filho, E. J. M. (2018). Consumer behavior regarding wearable technologies: Google Glass. Innovation \& Management Review, 15(3), 230-246. https://doi.org/10.1108/INMR-06-2018-0034 


\section{DISCUSSION}

Özbölük, T., \& Dursun, Y. (2017). Online brand communities as heterogeneous gatherings: A netnographic exploration of Apple users. The Journal of Product and Brand Management, 26(4), 375-385. https://doi.org/10.1108/JPBM-10-2015-1018

Paraskevaidis, P., \& Weidenfeld, A. (2019). Sign consumption and sign promotion in visitor attractions: A netnography of the visitor experience in Titanic Belfast. International Journal of Contemporary Hospitality Management, 31(4), 1937-1955. https://doi.org/10.1108/IJCHM-07-2018-0543

Park, E., Im, G., Storey, V. C., \& Baskerville, R. L. (2019). Never, never together again: How postpurchase affect drives consumer outcomes within the context of online consumer support communities. Journal of the Association for Information Systems, 20(1), 58-104. https://doi.org/10.17705/1jais.00529

Puttaiah, M. H., Raverkar, A. K., \& Avramakis, E. (2020, December 10). All change: How COVID-19 is transforming consumer behaviour. Swissre.com. https://www.swissre.com/institute/research/topics-and-risk-dialogues/health-andlongevity/covid-19-and-consumer-behaviour.html

PWC. (2020). Evolving priorities - COVID-19 rapidly reshapes consumer behavior. Pwc.com. https://www.pwc.com/us/en/industries/consumer-markets/library/covid-19-consumer-behaviorsurvey.html

Ranfagni, S., Faraoni, M., Zollo, L., \& Vannucci, V. (2021). Combining online market research methods for investigating brand alignment: The case of Nespresso. British Food Journal, 123(13), 37-58. https://doi.org/10.1108/BFJ-06-2020-0462

Richterová, K., et al. (2013). Úvod do výskumu trhu. Sprint 2.

Schembri, S., \& Latimer, L. (2016). Online brand communities: Constructing and co-constructing brand culture. Journal of Marketing Management, 32(7-8), 628-651. https://doi.org/10.1080/0267257X.2015.1117518

Schier, H. E., \& Linsenmeyer, W. (2019). Nutrition-related messages shared among the online transgender community: A netnography of youtube vloggers. Transgender Health, 4, 340-349.

Scholar.google.com (2021). Retrieved $11 \quad$ February 2021, from https://scholar.google.com/scholar?as_vis=1\&q=netnography\&hl=sk\&as_sdt=1,5.

Semanticscholar.org. (2021). Netnography | Semantic Scholar. [online] Available at: $<$ https://www.semanticscholar.org/search?q=netnography\&sort=relevance> [Accessed 11 February 2021].

Shuttleworth, M. (2008). Case study research design. Explorable.com. https://explorable.com/casestudy-research-design

Sloan, S., Bodey, K., \& Gyrd-Jones, R. (2015). Knowledge sharing in online brand communities. Qualitative Market Research, 18(3), 320-345. https://doi.org/10.1108/QMR-11-2013-0078

Tavakoli, R., \& Mura, P. (2018). Netnography in tourism - Beyond Web 2.0. Annals of Tourism Research, 73, 190-192. https://doi.org/10.1016/j.annals.2018.06.002

Thanh, T. V., \& Kirova, V. (2018). Wine tourism experience: A netnography study. Journal of Business Research, 83, 30-37. https://doi.org/10.1016/j.jbusres.2017.10.008

Toledano, M. (2017). Emergent methods: Using netnography in public relations research. Public Relations Review, 43(3), 597-604. https://doi.org/10.1016/j.pubrev.2017.03.007 


\section{DISCUSSION}

Tsandzana, D. (2019). Using online platforms to observe and monitor elections: A Netnography of Mozambique. Journal of Agricultural Education, 18, 46-71. https://doi.org/10.20940/JAE/2019/v18i2a3

Uzunboylu, N., Melanthiou, Y., \& Papasolomou, I. (2020). Hello brand, let's take a selfie. Qualitative Market Research, 23(1), 109-121. https://doi.org/10.1108/QMR-12-2017-0183

Villegas, D. (2018). From the self to the screen: A journey guide for auto-netnography in online communities. Journal of Marketing Management, 34(3-4), 243-262. https://doi.org/10.1080/0267257X.2018.1443970

Villers, S., Abrams, R., Anderson, S., Aung, M., \& Sweeney, E. (2020). Marketing insights: A netnographic study of the fitbit sleep better online community. The Journal of Applied Business and Economics, 22(11), 153-165.

Web of Science (2021). Netnography | Web of Science. [online] Available at: https://www.webofscience.com/wos/woscc/summary/1605d734-c012-43cd-8d25b44439754b65-1239193d/relevance/1 [Accessed 1 November 2021].

Wei, Y., Straub, D., \& Poddar, A. (2011). The power of many: An assessment of managing internet group purchasing. Journal of Electronic Commerce Research, 12(1), 19-43.

Whalen, E. A. (2018). Understanding a shifting methodology: A content analysis of the use of netnography in hospitality and tourism research. International Journal of Contemporary Hospitality Management, 30(11), 3423-3441. https://doi.org/10.1108/IJCHM-08-2017-0536

Xharavina, N., Kapoulas, A., \& Miaoulis, G. (2020). Netnography as a marketing research tool in the fashion industry in Southeast Europe. International Journal of Market Research, 62(4), 499-515. https://doi.org/10.1177/1470785319859210

Xun, J., \& Reynolds, J. (2010). Applying netnography to market research: The case of the online forum. Journal of Targeting, Measurement and Analysis for Marketing, 18(1), 17-31. https://doi.org/10.1057/jt.2009.29

Yin, R. (2017). Case study research and applications: Design and methods. Sage.

The discussion article passed the review process. | Received: July 29, 2021; Revised: November 22, 2021; Accepted: January 7, 2022; Pre-published online: March 7, 2022; Published in the regular issue: September 19, 2022 